\section{Em busca da} "República de Deus": revoltas

\section{camponesas}

e agentes da

emigração no

norte italiano

(século XIX)

\author{
Maíra Vendrame[1]
}

Resumo: $O$ presente artigo analisa o envolvimento de sacerdotes com o movimento emigratório das últimas décadas do século XIX, nas comunas da região do Vêneto, norte da península itálica. A atuação deles como agentes locais da emigração os tornaram alvos de perseguições por parte das autoridades do recémcriado Estado italiano. As experiências individuais e coletivas foram utilizadas como fio condutor para se inferir sobre questões mais gerais dos contextos estudados, permitindo, desse modo, propor novos questionamentos acerca das racionalidades camponesas e das dinâmicas sociais vividas no campo. Entendemos que tais procedimentos são fundamentais para elucidar o contexto político e social dos locais de partida dos emigrantes, envolvidos em protestos contra certos impostos e articulando a viagem para a América.

Palavras-chave: revoltas camponesas; sacerdotes; imigração italiana.

Searching for the "Republic of God": peasants' revolts and immigration agents in the North Italy (19th century)

Abstract: This article analyzes the involvement of priests with the migratory movement of the late nineteenth century, in the communes of the Veneto region, north of the Italian peninsula. Their role as places of emigration agents become targets of persecution on the part of the newly created Italian State. The individual and collective experiences were used as thread to infer more general issues of contexts studied, allowing thus propose new questions about the peasant rationalities and social dynamics experienced in the field. We understand that these procedures are fundamental to realize the political and social context of the place of departure of migrants, involved in protests against certain taxes and articulating the trip to America.

Keywords: peasant revolts; priests; italian immigration. 


\section{O pós-unificação e as revoltas no campo}

O território da Itália recém-unificada era atravessado por ideias anticlericais e dominado pelas intenções antirreligiosas de seus governantes liberais. Durante o processo de constituição do Estado italiano, a Igreja católica teve seus domínios territoriais extintos. A derrubada da Porta Pia e a tomada de Roma pelas tropas comandadas por Giuseppe Garibaldi, em 1870, colocaram fim ao poder temporal do papa. Foi em defesa da conotação leiga do Estado que grupos anticlericais passaram a contestar funções políticas e sociais dos clérigos junto à população italiana. Por outro lado, os representantes da Igreja católica faziam críticas às mudanças, objetivando retornar à sua posição anterior às disputas do ressurgimento. ${ }^{3}$

Nos centros urbanos da península itálica irão surgir iniciativas mais consistentes por parte dos novos grupos dirigentes no sentido de educar a população de acordo com o ideal progressista e nacionalista da pátria. A mediação desempenhada pelos padres nas questões relacionadas com a saúde e a educação será combatida pelos representantes da administração pública - grupo laico, patriótico, liberal e italiano. O novo Estado precisava conquistar base social entre a população comum, tanto urbana quanto rural. As divergências entre os padres e as autoridades públicas não foram incomuns nesse contexto pós-ressurgimento, especialmente pela compreensão "iluminista" de que a ignorância e o pensamento tradicional supersticioso do camponês eram mantidos e explorados pelo clero. Estes, acusados de fomentar divergências locais, eram vistos, em alguns lugares, como uma ameaça à manutenção da ordem pública (Bozzini, 2010). ${ }^{4}$

A insatisfação contra as novas leis do Estado italiano, especialmente com a criação de certos impostos, mobilizou os camponeses do norte da península na segunda metade do século XIX. Os padres tinham proximidade com a população do campo, assumindo papel de mediadores entre a paróquia e o mundo externo. ${ }^{5}$ A interlocução entre os camponeses e as instâncias de poder, como os proprietários e as autoridades públicas, era uma atividade que os paroquianos esperavam do sacerdote. Conhecedor das demandas, impasses e temores vividos pelas famílias nas comunidades, os párocos também temiam as mudanças e as consequências desastrosas em seu campo de atuação. Por esse e outros motivos, houve padres que se posicionaram como fortes apoiadores dos movimentos de protesto contra as novas leis do Estado italiano. A preocupação em relação ao avanço da desorganização das formas tradicionais de assistência religiosa no campo, com a quebra da estrutura social,

\footnotetext{
2 Episódio da unificação italiana que marca a anexação de Roma ao reino da Itália.

${ }^{3}$ Movimento que caracteriza o processo de unificação do território da península itálica, ocorrido entre 1815 e 1870.

${ }^{4}$ Frederico Bozzini, no livro L'arciprete e il cavaliere, aborda a região do Vêneto pós-ressurgimento durante a década de 1860 pela atuação de um padre da Bassa Veronese e um expoente da classe dirigente patriota. Ao fazer isso, o autor aponta para a oposição ideológica e os conflitos que irão marcar o território italiano no período em que o novo Estado irá buscar "fazer os italianos" e conquistar legitimidade social entre a população.

${ }^{5}$ Sobre a atuação dos párocos como mediadores no campo cultural e social - entre a baixa e a alta cultura - nas paróquias rurais da Itália setentrional, ver Allegra (1981).
} 
começou a fundamentar discursos "justicialistas e milenaristas" do clero (Bozzini, 2010, p. 108). Somando-se a isso, o aumento do medo da miséria e das doenças, aspectos esses que também irão aparecer como elementos utilizados pelos padres para incentivar a emigração. Entre as décadas de 1860 e 1870, passaram a ganhar força manifestações camponesas de protesto contra as autoridades liberais que representavam o reino da Itália. Assim, na sequência, conectados aos temores referidos e ao rompimento dos equilíbrios tradicionais locais, os padres começaram a incentivar os deslocamentos para o além-mar como forma de revolta social, dando início ao período conhecido como a "Grande Emigração".

Na região do Vêneto, nas pequenas comunas rurais, os padres aparecem como agentes que alimentavam o espírito revolucionário entre os camponeses descontentes com as exigências do Estado. As transformações institucionais, legislativas e econômicas que marcaram a Itália pós-unificação começaram a "revolucionar a ordem social no campo" (Casellato, 2012, p. 48). O mundo rural, atravessado por tensões, oferecia o fermento para a explosão de movimentos de contestação. Propiciou, também, o surgimento de movimentos milenaristas, a exemplo do guiado por David Lazzaretti ${ }^{7}$ que, em 1868, no monte Amiata, localizado na Toscana meridional, passou a pregar a instauração de uma "República de Deus", onde existiria justiça e não seriam mais pagas as taxas. Para além da questão da reforma social e política, eram muito fortes nos discursos de Lazzaretti as exaltações místicas e proféticas (Balduzzi, 2013). Tais ideias tiveram significativa adesão entre os trabalhadores rurais que seguiram Lazzaretti no monte Amiata, na cidade de Arcidosso. Isso mostra, na opinião de alguns estudiosos, a exemplo de Eric Hobsbawm, que a afinidade entre as explicações milenaristas e as revoltas é um dado fundamental para a compreensão da história dos movimentos camponeses em relação à modernização capitalista (Löwr, 2010, p. 110).

Em 1878, ano em que o "profeta" do monte Amiata foi morto pelas forças repressivas do Estado italiano, alguns padres também pregavam na região do Vêneto a necessidade do estabelecimento de uma "República de Deus". No entanto, esta deveria ser criada longe da Itália, mas precisamente na América, pelas famílias de camponeses que se sentiam oprimidas pelo Estado. Entre os paroquianos e indivíduos das comunas vizinhas, os clérigos se colocavam como apoiadores da emigração, organizando os grupos e orientando a partida para o Brasil. As populações do campo, insatisfeitas com as condições nas quais viviam, poderiam constituir no além-mar uma nova comunidade, livre das dificuldades políticas, econômicas e sociais vividas nas províncias italianas. Não foram poucas as manifestações de descontentamento dos camponeses com a realidade italiana da segunda metade do século XIX.

\footnotetext{
${ }^{6}$ O período de 1870 até 1920 é caracterizado pelos estudos migratórios, como a “Grande Emigração”, pois foi o momento em que da península itálica partiram grande número de indivíduos para a América.

7 David Lazzaretti, nascido em 1834, era um carroceiro convertido em pregador do evangelho em 1868. Começou como um novo profeta, "um reformador, um legislador pronto a liberar o povo que gemia". Inicialmente gozando da proteção da Igreja católica, afirmava querer formar "a milícia do Espírito Santo" para realizar a regeneração da ordem moral e civil (Löwr, 2010, p. 109).
} 


\section{Revoltas camponesas}

Na Itália recém-unificada, as primeiras manifestações de contestação às mudanças legislativas do Estado foram as revoltas antifiscais. Entre 1868 e 1869, todo o território peninsular é marcado por motins contra o macinato, ${ }^{8}$ imposto criado para taxar a moagem de grãos. Preferencialmente, os camponeses e os braccianti $i^{9}$ rebeldes se expressavam por meio da invasão dos moinhos, tentativas de assalto das ville padronali ${ }^{10} \mathrm{e}$ protestos aos prédios públicos no centro das comunas. Tendo ocorrido com intensidade variada nas diferentes províncias italianas, a região do Vêneto não presenciou confrontos tão violentos e com mortes, a exemplo do que aconteceu na comuna de Reggio Emília.."

Entendemos que a compreensão do contexto político e social no qual ocorreram as revoltas camponesas é importante para perceber as motivações daqueles que aderiram à ideia da emigração para a América. Mesmo constatando que os deslocamentos foram vividos também como uma forma de protesto social, os estudiosos do fenômeno migratório não se dedicaram a aprofundar as análises das racionalidades de protestos camponeses. Também não procuraram ampliar o leque de motivações que influenciaram as partidas, bem como o modo variado como as insatisfações e os temores vividos na terra de origem se manifestaram pelas ações cotidianas da população camponesa. Nesse sentido, o desempenho dos padres e o envolvimento com as famílias que tencionavam emigrar ajudam a entender o tipo de comunidade que desejavam constituir nas terras do território brasileiro destinado à colonização europeia.

Em pesquisa realizada nos Arquivos do Estado de Verona, Veneza e Bassano del Grappa, encontramos material documental sobre revoltas do macinato e os protestos de grupos que pretendiam emigrar da Itália na década de 1870 . Os processos-crime localizados apontam para a perseguição movida pelas autoridades contra certos padres. Suspeitos de atuarem como "agentes da emigração" nas comunas rurais, alguns sacerdotes foram acusados de incentivar os tumultos públicos, fazer propaganda do deslocamento e organizar a saída de grupos de famílias camponesas para o porto de Gênova. Assim, enquanto determinados padres orientavam os paroquianos a protestar junto às autoridades públicas, outros procuravam acalmar a população em favor da ordem pública.

Na comuna rural de Nogarole Rocca, na parte plana do território veronese, em 1868, começou um movimento de protesto contra o macinato, logo depois da participação da população nas cerimônias religiosas e festivas do dia de Santo Stefano. Apesar do controle das

${ }^{8}$ Imposto que passou a ser cobrado sobre a moagem da farinha. A obrigatoriedade da taxa foi imposta pela lei criada em 1868.

${ }^{9}$ Trabalhadores braçais que não tinham a posse da terra.

${ }^{10}$ Casas dos patrões e proprietários das terras.

"Alessandro Casellato (2012) faz uma análise dos motins do macinato ocorridos no Vêneto na segunda metade do oitocentos, em comparação com as revoltas acontecidas na Emilia-Romagna, estas descritas como mais violentas e radicais. 
autoridades policiais, no dia seguinte, apresentaram-se 150 pessoas na praça de Nogarole, que gritavam: "Viva a Áustria, viva o papa, morte aos senhores, morte ao macinato." Um dos líderes do protesto era o camponês Fioravante Bulesani, de 18 anos. Segundo a descrição do delegado, o líder do movimento levava um distintivo fixado ao chapéu, em que havia sido pintada a coroa papal com a inscrição "W Pio IX". Além disso, também carregava consigo um caderno com a relação de nomes de todas as pessoas que apoiavam as manifestações. Apresentando-se como "Presidenza della Plebe", o camponês Bulesani havia fixado na igreja um documento convocando a todos para se apresentarem na praça no dia 27 de dezembro de 1868. A recomendação era para que todos os manifestantes trouxessem um quarto de "sorgo turco". ${ }^{12}$ Durante o protesto, os grãos seriam levados até o moinho para que fossem triturados. ${ }^{13}$ Nesse caso, o pároco tentou persuadir os revoltosos em relação ao "insano protesto"; porém, não conseguiu evitar a continuação das manifestações. ${ }^{14}$

Os camponeses articuladores do movimento passaram a circular por Nogarele e povoados vizinhos procurando adesão da população ao protesto que objetivava impedir a manutenção da taxa da moagem. Assim, em uma das casas por onde passaram, foi fixado um manifesto com a seguinte declaração: "Cidadãos, não paguem as taxas sobre o macinato porque é imposta pelos senhores, e subscrevam-se para que possamos enviar à Firenze uma petição para que essa injusta taxa seja imediatamente abolida." Em reação, o pároco arrancou o documento declarando que não era compatível com as leis da Igreja e do governo. ${ }^{15}$ Assim, procurando acabar com as manifestações, perseguições e prisões de camponeses foram realizadas em vários locais da província de Verona.

Sob os gritos de "viva a Áustria, morte aos senhores e abaixo as taxas", a população de diferentes povoados demonstrou o descontentamento em relação ao Estado italiano e aos grandes proprietários, atacando os moinhos e os prédios públicos. Dando "vivas ao papa" e lançado críticas às autoridades públicas, muitos movimentos de protesto receberam apoio dos padres das aldeias, também descontentes com as mudanças daquele período. No campo político, a disputa entre os clérigos e os grupos dirigentes urbanos ganhava força pelo empenho dos primeiros em procurar manter os papéis sociais que tradicionalmente eram por eles desempenhados, recaindo sobre eles acusações de serem inimigos da pátria.

Nas comunas da região do Vêneto, durante os tumultos de 1869, o partido clerical era acusado de incentivar as oposições aos republicanos defensores do Estado italiano. Cabia aos administradores públicos e grupos liberais locais a responsabilidade de criar o sentimento de pertença e obediência às leis da nova pátria. Nesse sentido, era preciso "fazer os

\footnotetext{
${ }_{12}$ Espécie de milho muito consumido no norte da Itália.

${ }^{13}$ Arquivo do Estado de Verona (AEV). Relação dos policiais ao prefeito, 30 dez. 1868. Fundo Gabinete da Prefeitura, pasta 13.

${ }^{14}$ AEV. Relação do sindaco de Nogarole Rocca ao prefeito, 29 dez. 1868. Fundo Gabinete da Prefeitura, pasta 13.

${ }^{15}$ AEV. Relação do sindaco de Trevenzuolo ao prefeito, 28 dez. 1868; Relação dos policiais ao prefeito - Demonstração em Ronca Leva (Trevenzuolo), 1o jan. 1869. Fundo Gabinete da Prefeitura, pasta 13.
} 
italianos", educando a população com os valores da pátria e do progresso. A oposição do clero aos símbolos do novo Estado e aos projetos das classes dirigentes urbanas assegurava a existência de um clima de tensão entre os grupos.

Depois da unificação italiana, como forma de resistência aos ataques dos liberais, serão reforçadas as bases de agregação cultural e identificação sociorreligiosa nas paróquias, especialmente pela atuação dos padres diante das mudanças de uma sociedade "senza Dio" (sem Deus). Por meio de iniciativas associativas, as lideranças católicas locais irão acentuar o sentimento de pertença e "parrocchialità". Iniciativas variadas foram tomadas por alguns padres para reforçar a coesão e a assistência entre a população do campo, assumindo, portanto, uma conduta paternalista em relação aos paroquianos (Borzomati, 1997, p. 71-75).

Nas comunas rurais, a capacidade de se relacionar de forma autônoma com os camponeses, de compreender as aflições cotidianas vivenciadas pela população, garantia que os padres dispusessem de legitimidade, desempenhando papel fundamental na propagação de ideias, a exemplo da publicidade emigratória, conforme veremos a seguir. Os sacerdotes buscavam ter o controle da vida social, política e religiosa nas comunidades em que atuavam, procurando, ao mesmo tempo, reforçar os laços de confiança com a população, além de capitanear projetos individuais e familiares.

\section{Agentes da emigração}

A opção metodológica deste trabalho parte de experiências específicas, como o desempenho e as escolhas de determinados indivíduos, sejam eles padres ou camponeses. O referido método é entendido como recurso analítico que permite propor novos questionamentos para pensar questões como as racionalidades e articulações que propiciaram o fenômeno da imigração para a América. Para além das particularidades dos casos que serão apresentados neste artigo, os quais não se quer tomar como modelos para propor generalizações, busca-se apontar problemas gerais por meio das diferentes possibilidades percebidas nas situações específicas. Como exemplo disso, questiona-se o papel dos padres e dos discursos religiosos na organização das transferências para além-mar e na constituição de um ideal de comunidade pensado antes da partida da terra de origem. A ideia não é generalizar as especificidades, as experiências analisadas e as diferentes motivações e explicações, mas sugerir questionamentos amplos, que não seria possível se não fossem observadas as particularidades locais (Levi, 2009, 2015).

As dificuldades de manutenção das estruturas tradicionais de um modelo de vida comunitário, associadas aos problemas ligados à reprodução das famílias, eram sentidas tanto pelos camponeses quanto pelos párocos nas aldeias do norte da Itália. Por causa disso, ambos passaram a ver a emigração como uma forma de buscar oportunidades de sobrevivência. Nas últimas décadas do século XIX, passou a haver forte incentivo à transferência 
definitiva para a América, propaganda feita por padres e que se estendeu para várias comunas e províncias da região do Vêneto. Considerados promotores "clandestinos" da emigração e perseguidos pelas autoridades policiais por enganarem as famílias camponesas com falsas informações, alguns sacerdotes conseguiram organizar a viagem para o além-mar de muitos conterrâneos, dedicando-se a tal atividade com tenacidade. Eles sabiam dos riscos de se tornarem alvos de censuras e possíveis investigações por parte das autoridades do Estado italiano recém-unificado.

Um exemplo de atuação nesse sentido pode ser percebido no desempenho do sacerdote dom Ângelo Cavalli (35 anos), denunciado pelas autoridades do distrito de Bassano del Grappa por agir de forma "clandestina" como agente de emigração. Em junho de 1877, o delegado de polícia acusou Cavalli de ser "recrutador de imigrantes para a América" — fato esse conhecido entre a população. Em razão do "mau comportamento", o padre já teria causado "amargas desilusões a muitos infelizes que, acreditando em suas palavras, se privam de todos os seus bens, retornando infelizmente a este distrito". ${ }^{16}$

Na casa do sacerdote Ângelo Cavalli, localizada na comuna de Campolongo sul Brenta, província de Vicenza, foi apreendido um montante considerável de cartas e circulares que provavam seu envolvimento com o movimento emigratório. O material indicava a existência de contínua correspondência entre Cavalli e Clodomiro de Bernardes, diretor de agência de navegação, localizada no porto de Gênova, que estava organizando a transferência dos emigrantes para o Brasil. Agente oficial da emigração, Clodomiro emitia circulares com informações sobre as partidas e cartas com notícias sobre as regiões a serem colonizadas no território brasileiro. ${ }^{17}$ Portanto, por meio de correspondência, passava instruções diretas a certos indivíduos que se colocavam como organizadores da transferência dos familiares e grupos de conterrâneos. Pelas cartas, também eram informados os custos de transporte e a concessão de embarque gratuito para as famílias.

Considerado um agente "clandestino" por não ter autorização oficial para atuar como promotor da emigração, o padre Cavalli emitiu carta para o brasileiro Caetano Pinto ${ }^{18}$ solicitando embarque gratuito em um mesmo navio para um grupo de pessoas conhecidas que pretendiam partir para o Brasil..$^{19}$ A participação do sacerdote como intermediador da emigração deu aos camponeses italianos segurança na hora de decidir pela viagem, pois dom Ângelo era conhecido e gozava de boa reputação. Em consequência disso, mais pessoas

${ }^{16}$ Arquivo do Estado de Bassano del Grappa (AEBG). Carta-denúncia das autoridades policiais destinada ao delegado distrital de Bassano, 10 jun. 1877. Processo-crime, 1877, pasta 107, fascículo 163.

${ }_{17}^{17}$ AEBG. Processo contra o sacerdote Ângelo Cavalli, 1877, pasta 107, fascículo 163.

${ }^{18} \mathrm{Na}$ década de 1870, o governo imperial brasileiro firmou contrato com o proprietário Joaquim Caetano Pinto Júnior, que o autorizava a introduzir no Brasil, no prazo de 10 anos, 10 mil imigrantes europeus.

${ }^{19} \mathrm{O}$ padre prestou esclarecimentos ao delegado de Bassano del Grappa sobre a maneira como vinha se organizando para emigrar juntamente com os irmãos e conhecidos da província de Vicenza, bem como as vantagens a eles oferecidas no Brasil. Desse modo, procurou demonstrar o quanto eram legítimas e corretas as atitudes que estava tomando (AEBG. Processos contra o sacerdote Ângelo Cavalli, 1877, pasta 107, fascículos 163 e 179). 
foram aderindo à ideia da emigração, e, uma vez tomada a decisão, os camponeses colocaram em prática uma dinâmica autônoma para as transferências das famílias, constituindo uma rede de comunicação que extrapolava e muito o âmbito parental, alcançando pessoas de outras comunidades a fim de buscarem informações entre aqueles que tinham parentes já emigrados (Vendrame,2016)

Na percepção das autoridades policiais e políticas da Itália, os emigrantes eram compreendidos como "ingênuos camponeses" que aderiam às falsas propagandas dos subagentes "clandestinos". No entanto, a lógica da população do campo envolvia uma logística complexa e muito bem articulada, passando longe da "ingenuidade" acreditada pelas autoridades. Os camponeses procuravam se informar junto a pessoas de confiança, buscando adquirir o maior número possível de informações não somente sobre a viagem, mas também a respeito das vantagens que conseguiriam nas regiões de destino. Portanto, no momento da partida, muitos já apresentavam dados privilegiados sobre as facilidades e oportunidades que encontrariam nas áreas de ocupação no Brasil.

Por meio das cartas que estavam com o padre Cavalli, é possível perceber a existência de um amplo circuito de informações que fornecia subsídios às famílias antes de abandonarem a terra natal. Quando foi denunciado pelas autoridades policiais, Cavalli se encontrava temporariamente suspenso das "funções eclesiásticas", sendo investigado por dirigir uma "perversa empresa" que recebia dinheiro dos camponeses que ajudava a emigrar. ${ }^{20}$ Entre a população era notório que há algum tempo o sacerdote vinha desempenhando a atividade de agente, circulando por diversas comunidades da região do Vêneto. Apesar dos riscos de ser perseguido pelas autoridades e cair nas malhas da justiça, o padre Cavalli continuava a desempenhar o papel de agente da emigração. O referido sacerdote estava, segundo o inspetor de polícia, "divulgando em alta voz um próximo embarque para a América", incitando, desse modo, "a mania febril dos pobres iludidos". ${ }^{21}$

Além do anúncio da partida de nova embarcação para o Brasil, de acordo com os comentários locais, o padre agenciador havia viajado para Gênova e Veneza para resolver questões relacionadas com a transferência de um grupo de emigrantes. ${ }^{22}$ Os frequentes deslocamentos de Ângelo Cavalli confirmam que ele continuava a desempenhar a função de "agente ilegal da emigração", apesar da abertura de investigação contra seu procedimento. De Gênova, de fato haviam partido duas embarcações, formadas, em sua maior parte, por grupos de emigrantes "tiroleses e do Asiago Vicentino". E ambos os grupos tinham sido "arrolados por Dom Ângelo Cavalli" ${ }^{23}$ comprovando, desse modo, seu envolvimento com o movimento emigratório.

${ }^{20}$ AEBG. Processo-crime, 1877, pasta 107, fascículo 163.

${ }^{21}$ AEBG. Carta-denúncia das autoridades policiais destinada ao delegado distrital de Bassano, 10 jun. 1877. Processo-crime, 1877, pasta 107, fascículo 163

22 AEBG. Nova denúncia, 14 jul. 1877. Processo-crime, 1877, pasta 107, fascículo 179.

${ }^{23}$ Arquivo Comunal de Montebelluna (ACMB). Carta reservada de Bonaventura dell'Eva ao sindaco de Montebelluno, 1877, pasta 550. 
Procurando garantir a transferência de todos os inscritos de sua lista, o referido sacerdote se muniu das orientações transmitidas pela empresa de navegação de Clodomiro de Bernardes. Por meio de cartas, circulares e notícias buscadas junto ao consulado do império brasileiro, localizado em Veneza, o sacerdote forneceu as informações necessárias aos conterrâneos que lhe procuravam. Não poucas vezes, dom Ângelo fazia pequenos discursos em cafeterias e feiras, de diferentes comunas das províncias de Treviso e Vicenza, explicando os caminhos da emigração para aqueles que desejavam partir da Itália.

Em maio de 1877, o cônsul do Brasil em Veneza, Leopoldo Bizio, afirmou ser intenso o fornecimento de informações para aqueles que se deslocavam até o consulado. Apesar de recomendar cautela à população, disse que o padre Cavalli "animava o espírito dos emigrantes" nas províncias do Vêneto, desencadeando em alguns lugares graves desordens. Em face do contínuo aumento dos deslocamentos e do surgimento de tumultos por parte das famílias que retornavam exaltadas dos portos da região, visto não terem conseguido embarque gratuito, a autoridade consular destacava que nenhuma instrução havia sido transmitida pelo governo imperial brasileiro aos agentes consulares na Itália, nem para recrutar, nem para conceder facilitações de viagens, nem, ainda, para "favorecer qualquer modo de emigração". ${ }^{4}$

Provavelmente, o padre Cavalli tinha tomado conhecimento das recomendações passadas pelo consulado brasileiro em Veneza, visto ter visitado o estabelecimento após a emissão da circular — entre os meses de junho a agosto de 1877. Nesse caso, a adoção de precauções de sua parte se reflete na iniciativa de encaminhar carta a Caetano Pinto, encarregado pelo império do Brasil de introduzir imigrantes no país. Entre as garantias solicitadas, demandou que fosse fornecido embarque em uma única expedição para um grupo de famílias que se encontrava sob sua direção. O padre Cavalli tomou tal atitude após ser informado por Clodomiro de Bernardes que os embarques para o território brasileiro se encontravam suspensos. ${ }^{25}$

Procurando escapar das perseguições por parte das autoridades, em fevereiro de 1877, padre Cavalli comunicou ao delegado do distrito de Bassano del Grappa que em abril ele partiria junto dos irmãos e de algumas famílias conhecidas para o Brasil. As viagens já estavam certas, declarando ter se deslocado até Gênova para pessoalmente acordar com Clodomiro de Bernardes o embarque e certificar-se das condições oferecidas aos familiares e aos outros emigrantes. ${ }^{26}$ No entanto, padre Cavalli não cumpriu com a afirmação de que iria partir, preferindo continuar a atuar como agente da emigração, como o fez durante todo aquele ano.

Durante os primeiros anos da emigração da Itália para o Brasil, não foi incomum a partida de padres juntamente com os paroquianos e conhecidos. Os motivos para abandonarem a pátria são variados, desde os que tinham o desejo de também "fazer fortuna na América"

${ }^{24}$ Arquivo do Estado de Veneza (AEVE). Circular emitida pelo Consolato Imperiale del Brasile in Venezia, Leopoldo Bizio, 28 maio 1877. Processos: Tribunal Civil e Correcional de Veneza, Processos 1877, pasta 940, fascículo 64.

${ }^{25}$ AEBG. Depoimento de Clodomiro de Bernardes na delegacia de Gênova, 6 jun. 1877. Processo-crime, 1877, pasta 107. fascículo 163

${ }^{26}$ AEBG. Carta ao comissário do distrito de Bassano del Grappa, 12 fev. 1877. Processo-crime, 1877, pasta 107, fascículo 163. 
até os que emigravam com a intenção de realizar trabalho missionário entre as famílias camponesas italianas, garantindo, assim, a preservação dos valores católicos. Partiram por conta própria junto com familiares ou amigos, financiados pelos conterrâneos que já se encontravam no além-mar, ou, ainda, impulsionados por perseguições, conflitos e dificuldades pessoais e familiares de convivência nas comunas do norte italiano, por serem suspeitos de cometer infrações quanto ao "voto de castidade". ${ }^{27} \mathrm{O}$ caminho da emigração se apresentava, portanto, como uma possibilidade de mudar o próprio destino, conquistar novo status social e ampliar as oportunidades individuais e familiares. Independentemente da diversidade das condições e motivações das partidas, estas permitem inferir as racionalidades presentes no universo camponês. O peso dos aspectos psicológicos, sociais, religiosos e reprodutivos, somado às dificuldades econômicas e demográficas já ressaltadas pela historiografia do deslocamento transatlântico, é algo que ainda precisa ser estudado. O presente artigo pretende chamar a atenção para a necessidade de pesquisas nessa direção.

O desempenho do padre Ângelo Cavalli como agente local está ligado ao desejo de também se transferir para as terras brasileiras e estabelecer-se junto aos familiares e conhecidos. Segundo afirmação do imigrante Giulio Lorenzoni (2008), o referido sacerdote era um "moço inteligente e cheio de vida", tendo se hospedado na casa de um dos principais moradores do lugar onde residia antes de partir para o Sul do Brasil. Ali, em reunião com alguns indivíduos e chefes de família, explicou como iria ocorrer "la traversata sull'oceano" (a travessia do oceano). Forneceu esclarecimento sobre as condições e etapas da viagem que deviam ser seguidas por aqueles que decidissem emigrar. Aos interessados, explicou também os favores e as vantagens que o governo brasileiro conferia aos recém-chegados: casa, alimentação, terra, instrumentos agrícolas e sementes. Nas reuniões que antecediam o deslocamento, Ângelo Cavalli "comparava o Brasil a uma segunda Canaã”, acrescentando, ainda, que naquele lugar "a vegetação era exuberante, a terra produzia extraordinariamente sem muito trabalho" (Lorenzoni, 2008, p. 5-6).

Com a propaganda realizada pelo referido sacerdote, formaram-se grupos de famílias decididas a partir para a América. Entre estas se encontrava a família de Júlio Lorenzoni, filho de um pequeno proprietário que, após vender as posses e os bens, juntou-se a outros conhecidos de Mason, província de Vicenza, que se dirigiam para Gênova. ${ }^{28}$ Segundo Lorenzoni, tal transferência representava a possibilidade de a família interromper a migração sazonal do patriarca em busca de trabalho temporário para países vizinhos, como muitos camponeses faziam. ${ }^{29}$ Isso porque, nas regiões de colonização do território brasileiro, iriam obter terras de cultivo suficientes para garantir a sobrevivência e a reprodução social do grupo.

${ }^{27}$ Emílio Franzina (1995, p. 225-228) aponta algumas trajetórias de padres fugidos ou expulsos da pátria que migraram para os Estados Unidos.

${ }^{28}$ Relação de imigrantes da ex-colônia Silveira Martins, 1882 (Righi, 2001, p. 140).

${ }^{29}$ O imigrante Júlio Lorenzoni (1975, p. 14) afirma que, antes de partir para a América, havia presenciado o pai partir para os países do exterior - Suíça, Austria e Alemanha - em busca de serviço. 
Assim, em fevereiro de 1878, o imigrante Júlio Lorenzoni chegou à colônia Silveira Martins, localizada no centro do Rio Grande do Sul, juntamente como os familiares, instalando-se em uma das comunidades do lugar.

Naquele mesmo ano também chegava à referida região colonial um grupo de imigrantes da província de Treviso que havia recebido auxílio de um padre para organizar a transferência para o Brasil meridional. Como Ângelo Cavalli, o sacerdote João Solerti também orientava os camponeses, da comuna de Piavon e localidades vizinhas a tomarem tal caminho como alternativa para melhorar as condições de vida.

Chamado de "fanático" pelas autoridades locais, João Solerti foi um dos principais articuladores da emigração de um grupo de paroquianos que pretendia fundar uma nova comunidade em um núcleo de colonização no Rio Grande do Sul. ${ }^{30}$ Ao condenarem o procedimento do referido sacerdote como incentivador das transferências para a América, as autoridades afirmavam que ele já fora condenado ao cárcere por truffa ${ }^{31}$ - fraude, falsificação, embuste, trapaça. Tais acusações diziam respeito a fatos ocorridos muito antes, no período em que havia trabalhado em uma paróquia rural da província de Treviso na década de 1860.

O referido padre havia sido preso juntamente com outros paroquianos por suspeitas de roubo, fraude e posse ilegal de arma de fogo. Porém, pela falta de provas, nada ficou comprovado sobre a participação do sacerdote no furto ocorrido na referida comunidade. ${ }^{32}$ As acusações que recaíam sobre Solerti e outros paroquianos estavam ligadas a certos tipos de procedimentos que as autoridades do Estado italiano procuravam controlar como forma de legitimar as mudanças que a nova ordem política havia provocado. Os furtos campestres tinham papel significativo no território da península itálica nas décadas de 1860 e 1870, uma vez que as transformações acarretadas pelo processo de unificação significaram alterações no modo como os camponeses garantiam a obtenção dos recursos necessários para a sobrevivência do grupo familiar. As proibições do governo italiano em relação ao uso das terras públicas, que tradicionalmente eram locais de que a população tirava madeira e também colhia frutos, desencadearam revoltas e perseguições.

Camponeses e padres da província de Treviso caíram nas malhas da justiça porque esta estava empenhada na repressão aos eventos de contestação e furtos campestres. Frequentemente, a coordenação de tais ações recaía sobre os padres que atuavam nas paróquias rurais, e alguns deles foram presos. Das autoridades diocesanas, por outro lado, partiam orientações para que os sacerdotes observassem as leis do Estado, porém isso não foi

\footnotetext{
${ }^{30}$ Entre esses emigrantes, estavam o camponês Paulo Bortoluzzi e o amplo agregado de famílias do distrito de Oderzo, província de Treviso. Sobre o caso, ver Vendrame (2016).

${ }_{31}$ Arquivo Comunal de Treviso (ACTV). Resposta do conde Luiz Revedin, Questionário do Ateneo di Treviso, 3 fev. 1878, pasta 13, fascículo 2. Em maio de 1877, em um dos jornais de maior circulação da província de Treviso, João Solerti foi denunciado por estar trabalhando ativamente na emigração das famílias de Piavon (Biblioteca Universitária de Padova [BUPD]. Emigração. Gazzetta di Treviso, 10 maio 1877).

${ }^{32}$ Arquivo da Diocese de Treviso (ADTV). Relatório de conclusão das investigações contra o padre João Solerti, 9 nov. 1866
} 
seguido por todos. ${ }^{33}$ Em fevereiro de 1868, em carta encaminhada ao bispo de Treviso, um colega de batina considerava "perigosa a permanência do capelão dom Solerti na paróquia" de Pagnano, uma vez que mantinha "perversa intimidade" com alguns indivíduos de "má fama" do lugar. Solicitava, portanto, a transferência do referido sacerdote. ${ }^{34}$ Para tentar evitar o surgimento de novas desordens, escândalos ${ }^{35}$ e garantir a boa administração das paróquias no território da península itálica, os sacerdotes que causavam certos problemas eram transferidos para outras comunidades como medida de controle dos comentários e ameaças locais. Isso foi o que ocorreu com João Solerti, mudando-se para a comuna de Piavon na metade da década de 1870.

No entanto, na nova paróquia, o referido sacerdote continuou a se envolver com questões que iam além daquelas relacionadas com a administração dos bens da igreja e a assistência religiosa aos fiéis. Diferentemente das acusações anteriores, em Piavon, Solerti, igualmente como Ângelo Cavalli, foi acusado de ser um incentivador da imigração para a América. Por meio de "discursos empolgantes", fazia surgir a "esperança entre a população camponesa de que poderiam melhorar a própria sorte" no além-mar. E, ainda: que longe da pátria teriam liberdade para "conservar sua religião". Além disso, apresentava o Brasil como a "terra da promissão", assegurando que "na Itália a religião católica desapareceria”, que a "população seria destruída pela peste, fome e guerra", e que todos cairiam "sob o domínio Turco"; e que "um novo papa seria eleito do outro lado do Atlântico". ${ }^{36}$ Igualmente como o padre Cavalli, parece que Solerti transmitia em seus discursos uma imagem positiva das vantagens que as famílias camponesas poderiam encontrar na América, uma delas sendo a liberdade de constituir novas comunidades católicas, longe das ameaças e dos problemas enfrentados na pátria de origem.

Padre João Solerti foi acusado pelas autoridades, pela imprensa e pelos intelectuais de ser "fanático" e "intransigente", sendo um dos mais destacados instigadores da emigração no distrito de Oderzo. ${ }^{37}$ Além de fomentar a fuga das famílias camponesas, "atuava como um procurador representante da companhia [navegação] nas comunas de Treviso”. Somado a isso, um dos jornais da província de Treviso denunciava o fato de o sacerdote "pregar a decadência da religião na península e orientar os camponeses a fundar uma colônia religiosa na América”. ${ }^{38}$ Por tudo isso, é provável que a permanência de Solerti em Piavon tenha se

${ }^{33}$ Alessando Casellato (2012), estudando os motins do macinato no Vêneto, aponta para as experiências de outros padres na província de Treviso perseguidos pela justiça por terem cometido furtos e liderado agitações.

${ }^{34}$ ADTV. Carta ao bispo da diocese de Treviso do pároco de Pagnano, Antônio Zamboldi, em 6 de fevereiro de 1868. Pasta João Solerti.

${ }^{35}$ ACTV. Também pesava sobre o padre João Solerti outra acusação: a de ter violado os códigos de boa conduta moral. Resposta do conde Luiz Revedin, Questionário do Ateneo di Treviso, 3 fev. 1878, pasta 13, fascículo 2.

${ }^{36}$ ACTV. Resposta de Luiz Revedin, Questionário do Ateneo di Treviso, 3 fev. 1878; Relação final do Ateneo de Treviso, Luiz Bailo, 1878, pasta 13, fascículo 2

${ }^{37}$ ACTV. Resposta de Luiz Revedin, Questionário do Ateneo di Treviso, 3 fev. 1878, pasta 13, fascículo 2.

${ }^{38}$ ACTV. A emigração. Gazzetta di Treviso, 10 dez. 1887. 
tornado insustentável, pois, depois de apoiar e assistir à partida de alguns camponeses para o Sul do Brasil, em 1887, o referido padre parece ter desaparecido do lugar.

Os discursos dos padres, que incitavam à revolta e à fuga para a América, e a rapidez com que as famílias camponesas vendiam seus bens a fim de partir para o outro lado do Atlântico fizeram com que a imprensa condenasse as transferências e censurasse a atuação dos indivíduos que se destacavam como incentivadores da causa migratória. Isso foi o que ocorreu contra o padre João Solerti. ${ }^{39}$

A propaganda de que na América as famílias camponesas encontrariam a liberdade, uma vez que estariam em um espaço para reconstruir as vidas de acordo com suas práticas e crenças, era realizada por padres “intransigentes", preocupados com o rompimento do "corporativismo rural" que caracterizava o território da paróquia. O pároco buscava garantir a manutenção das formas tradicionais de assistência, a identidade religiosa e social, o modelo de família patriarcal e a ligação do pequeno proprietário com a terra. Assim, a segunda metade do século XIX, marcada pelas transformações que afetavam a sociedade civil, como a presença de novas ideias - liberais e maçônicas - , a expropriação do patrimônio eclesiástico e a perda de espaço, motivará o surgimento, especialmente entre o clero rural, de um discurso religioso de "reconquista" (Lanaro, 1976). Essa reconquista poderia significar o reforço ou a preservação das alianças e relações dos padres com seus paroquianos em terras no além-mar, onde novas comunidades seriam fundadas a partir da transferência de amplo grupo de famílias oriundas de um mesmo local. Nesse sentido, o incentivo do padre Solerti à imigração para o Brasil meridional, sustentado por discurso "apocalítico" de fim da religião católica na Itália, se manifesta, portanto, como uma estratégia para garantir a ligação dos camponeses com o catolicismo vivido nas paróquias. Além disso, possibilitava a preservação das práticas assistenciais e corporativas tradicionais, bem como dos papéis e controles exercidos pelos padres de aldeia.

A possibilidade de fundarem associações religiosas, estabelecendo as estruturas agregativas da vida comunitária nas novas terras, era apenas um dos elementos que, somados a outros, fomentavam as transferências de amplos grupos de famílias que tinham mesma origem e condição social. Contudo, o encorajamento ao abandono da pátria também fora vivido como uma forma de se manifestar contra as novas instituições do Estado liberal italiano, considerado este o responsável pelas dificuldades socioeconômicas que atingiam as populações rurais. Além de se revoltarem contra a cobrança de taxas e proibições, alguns padres foram perseguidos pela justiça por não respeitarem as novas leis estabelecidas.

Ressaltando o papel das lideranças religiosas na sociedade rural durante as últimas décadas do século XIX, um proprietário da província de Belluno afirmou que o padre era o sujeito mais importante no universo camponês, como autoridade política e religiosa. Segue expondo que "a relação entre o pároco e os paroquianos é contínua, porém, às vezes, é cordial

${ }^{39}$ ACTV. Brunetti, Antônio. A emigração no distrito de Oderzo. Gazzetta di Treviso, 11, 12, 13 e 17 jan. 1888. 
e outra é áspera, sendo ele ora o pastor espiritual, ora confidente, o conselheiro dos camponeses, ou ainda, o seu advogado e protetor". Logo, exercitavam significativa influência entre os paroquianos (Maresio Bazolle, 1868-1890 apud Zannini, 2003, p. 300). A importância social, política e religiosa dos padres entre a população do campo é um aspecto que aparece presente quando da partida dos italianos para a América. ${ }^{40}$

Os sacerdotes que incentivavam as transferências das famílias camponesas, ao contrário de ludibriarem paroquianos e conhecidos ao falarem das possíveis vantagens a serem encontradas no além-mar, confiavam no caminho da emigração como uma possibilidade vantajosa para muitos, inclusive para eles. Em carta, padre João Solerti mencionou que "sempre havia carregado consigo a vontade de acompanhar os conterrâneos até o outro lado do Atlântico". Assim, na última década do século XIX, após tantas súplicas dos conhecidos distantes expressadas por correspondências, depois de ter assistido à partida de muitos conhecidos, decidiu embarcar para o Brasil para trabalhar nas regiões ocupadas por italianos.

Contudo, passados apenas dois meses, Solerti foi obrigado a retornar para a península itálica, uma vez que havia partido sem documento de liberação da diocese de origem. ${ }^{41} \mathrm{~A}$ posse das cartas de liberação era um fator que garantia a permanência segura nos locais de destino. Muitos foram os padres imigrantes que chegaram ao Brasil meridional sem permissão das autoridades diocesanas ou apenas com licenças temporárias de permanência. Porém, é também provável que Solerti tivesse escapado da pátria de origem pelas crescentes perseguições que vinha enfrentando por parte das autoridades italianas. Independentemente dessa questão, por meio das experiências dos dois padres aqui apresentadas, pretende-se reforçar o quanto a imigração para a América esteve ligada à atuação de mediadores locais que dispunham da confiança da população. Sem desconsiderar, portanto, que conflitos e condenações morais por parte de indivíduos da paróquia também motivaram a partida dos padres para o além-mar.

Havia uma quantidade grande de informações sobre as transferências e os locais de colonização na América meridional que circulava pelas redes de apoio nas comunas italianas. A recepção e a credibilidade das notícias passavam pela relação de confiança entre aquele que transmite e o que solicitava esclarecimentos sobre a viagem e os lugares de transferência. Mas, para ganharem credibilidade, precisavam ser transmitidas por conhecidos que dispunham de certo respeito ou que faziam parte da rede de contatos parental e de vizinhança. A questão da confiabilidade entre as famílias camponesas e os padres agentes é considerada um dos principais fatores que permitiram que os últimos tivessem certo sucesso ao atuarem como agentes da emigração (Brunello, 1983). As correspondências trocadas entre familiares e conterrâneos que se encontravam em ambos os lados do Atlântico foram usadas pelos padres e camponeses para comprovar a legitimidade de determinados discursos e fortalecer

${ }^{40}$ Sobre o papel dos padres na região do Vêneto no período da imigração para a América, ver Franzina (2006).

${ }^{41}$ Arquivo da Diocese de Treviso (ADTV). Carta de João Solerti, 8 dez. 1893, pasta de João Solerti. 
as redes de comunicação e confiança. Procurando compreender melhor o desempenho dos sacerdotes nas comunas italianas junto às populações rurais, veremos na sequência a atuação de outro indivíduo que criou problemas à ordem pública em face do não sucesso da transferência de um grupo de famílias que havia optado pelo caminho da emigração.

\section{Padre incitador da revolta}

Na comuna de Marcon, município de Mestre (próximo a Veneza), o sacerdote Giobatta Frizzo foi apontado como um dos principais responsáveis por incentivar os protestos de camponeses contra as autoridades. Diante da frustrada tentativa de emigrar, algumas famílias tiveram de retornar do porto de Gênova, o que deu início à revolta de homens, mulheres e jovens que demandavam a assistência da comuna, já que se encontravam desocupados. Como medida paliativa, os manifestantes foram empregados em obras públicas nas estradas municipais. Porém, a iniciativa não impediu o surgimento de novos protestos, principalmente porque o valor das diárias foi considerado baixo pelos camponeses, insuficiente para garantir a sobrevivência dos trabalhadores.

Demonstrando insatisfação, os manifestantes, frustrados em seus projetos de imigrar para a América, se reuniram em frente à casa comunal. Ali se apresentou uma "turbe de mulheres" que, por meio de gestos de ameaças e insultos, manifestavam indignação contra o procedimento das autoridades municipais, cantando a seguinte canção improvisada: "Noi lavoriamo sulla strada, ma de quei del município no gavemo paura, ghe daremo uma sciopetada e li manderemo in sepoltura". ${ }^{42}$ Diante do protesto, o delegado do distrito de Mestre afirmou que os tumultos contínuos na comunidade de Marcon tinham por objetivo subverter a ordem das coisas. Portanto, era necessário agir duramente contra os “chefes promotores", especialmente contra o padre Frizzo, "um dos líderes do movimento". Medidas repressivas deviam acabar com as ameaças frequentes dos camponeses e impedir que seus guias continuassem a orquestrar "secretas reuniões". 43

O comportamento de dom Frizzo já vinha sendo alvo de questionamento, tendo, em tempo anterior, o delegado alertado o quanto era perigosa a permanência na paróquia de um "padre reacionário e incitador de revolta", que exercia grande "influência sobre os camponeses". Além disso, o sacerdote era acusado de "andar de casa em casa sem precaução alguma, espalhando ideias de liberdade". Por tudo isso, solicitava o afastamento de dom Frizzo da comuna de Marcon o mais breve possível. Considerava "perigoso" e "absolutamente indecoroso

$\overline{42}$ Arquivo do Estado de Veneza (AEVE). Relatório do comissário do distrito de Mestre ao prefeito de Veneza, 14 jun. 1877. Processo verbal. Gabinete da Prefeitura, 1877-1881, 19, 2-1. Tradução da canção: "Nós trabalhamos na estrada, e daqueles do município [autoridades] não temos medo, Ihes daremos um tiro e os mandaremos para a sepultura".

${ }^{43}$ AEVE. Ibid. 
que um padre investigado por contrabando, posse de arma e [por] instigar a clandestina emigração" se conservasse na paróquia em que havia sido capturado. ${ }^{44}$

Diante do fracasso da intenção de emigrar, após algumas famílias terem retornado do porto de Gênova para a comuna, elas passaram a protestar acusando "os senhores" (i padroni) de trabalharem contra o projeto emigratório. ${ }^{45} \mathrm{Na}$ opinião do delegado, o padre Frizzo visto como o incentivador da emigração - era o maior responsável pelo contexto de revolta. Porém, no decorrer das investigações, as pessoas não o denunciaram como agente, afirmando que somente "Deus os tinha inspirado a emigrar e ninguém mais". Justificativa óbvia usada para proteger a identidade do sacerdote.

Apesar da não colaboração das famílias de Marcon, o delegado consolidou as certezas que tinha em relação ao desempenho de dom Frizzo. Logo, apontou ser ele um dos "instigadores habituais, afilhado ao partido clerical e internacional", do qual faziam parte muitos "fanáticos pela emigração para o Brasil". Também denunciou que, em abril de 1877, o referido sacerdote teria expressado publicamente que "dois dias de comunismo não fariam mal", discurso feito quando se encontrava entre um grupo de camponeses de uma comuna rural pertencente a Mogliano Veneto. Por todos os motivos apresentados, padre Frizzo foi considerado responsável por instigar os camponeses a organizar manifestações públicas contra o peso excessivo das taxas do macinato — moagem da farinha - e exigir a concessão de "pão e trabalho" às famílias desocupadas.

Apesar dos conflitos locais contra alguns proprietários e autoridades públicas contrárias à imigração para a América, ${ }^{46}$ padre Frizzo não pode ser descrito apenas como incentivador da insurreição dos camponeses. Ele se apresentou como defensor dos direitos da população diante das novas taxas e leis consideradas injustas. Colocou-se como representante dos arrendatários, bracciante, camponeses e desocupados que estavam enfrentando dificuldades de sobrevivência. Mais que apenas demonstração de oposição aos grandes proprietários, o sacerdote buscou abrir caminhos para o estabelecimento de acordos com as instituições do recém-criado Estado italiano. O desempenho como mediador pode ser constatado pela carta que enviou ao ministro solicitando mudança em relação às novas taxas sobre a farinha, apontando serem essas as causas dos grandes descontentamentos entre a população. ${ }^{47}$

Atingido da mesma forma pelos problemas enfrentados pelos camponeses, padre Frizzo também se manifestou publicamente contra o médico e sindaco de Mogliano Veneto, Girolamo Bianchi. Contra ele, escreveu manifesto em nome da população acusando-o de negligenciar os deveres para com os pobres para "ir caçar nas vastas extensões de pântano" (Scroccaro,

${ }^{44}$ AEVE. Carta ao prefeito de Veneza do delegado distrital de Mestre, 3 jun. 1877. Carta do delegado ao prefeito da provincia de Veneza, 26 maio 1877. Gabinete da Prefeitura, 1877-1881, 19, 2-1.

${ }^{45}$ AEVE. Carta do delegado ao prefeito da província de Veneza, 26 maio 1877. Ibid

${ }^{46}$ ADTV. Carta enviada ao bispo pelo pároco da paróquia de Santo Stefano di Treviso, 12 maio 1877, pasta sacerdote Giobatta Frizzo.

${ }^{47}$ AEVE. Carta do padre Giobatta Frizzo enviada ao ministro de assuntos interiores, 10 jul. 1876. Tribunal Civil e Correcional de Veneza, Processo, 1877, fascículo 414. 
2010, p. 81). Contra o sindaco Bianchi recaía a acusação de ter retardado a partida dos emigrantes para o porto de Gênova, tendo ele, em contrapartida, denunciado o padre à justiça. ${ }^{48}$ Entre dom Frizzo, empenhado em reforçar os vínculos que tradicionalmente ligavam os sacerdotes a seu rebanho, e os indivíduos que ocupavam cargos públicos na comuna existiam, certamente, divergências ligadas a questões de ordem moral e política.

O apoio do padre à emigração sinaliza essa oposição entre o sacerdote - representante dos camponeses e bracciante - os proprietários e funcionários públicos. Além disso, seu desempenho também se justifica como um recurso de contra-ataque e vingança em relação às perseguições públicas que vinha sofrendo das autoridades locais. Nesse sentido, a decisão pelo deslocamento para o além-mar também era vivida como uma forma de protestar contra as novas leis, restrições e controles sentidos nas comunas da Itália pós-ressurgimento, bem como de atacar os proprietários e a elite política local contrária à saída das famílias dos campos. Somado a tudo isso, a imigração para a América era ainda percebida como uma saída para garantir a preservação das práticas religiosas tradicionais que caracterizavam as sociedades camponesas.

\section{A “República de Deus” na América}

O contexto local de onde partiram os emigrantes era um cenário de disputas entre os apoiadores e os que se opunham às transferências das famílias camponesas. Frequentemente, esse conflito ocorria entre os padres e as autoridades públicas, uma vez que os primeiros aparecem, muitas vezes, como incentivadores e organizadores de protestos nas comunas e da partida das famílias camponesas para a América, conforme vimos anteriormente. Tal desempenho se constitui em um contexto de oposição ao Estado liberal italiano e em sintonia com o movimento geral da Igreja contra as mudanças do mundo moderno. Porém, o desempenho desses sacerdotes no campo se refere mais à sua capacidade de se relacionar de maneira autônoma com os camponeses do que em razão das orientações vindas de Roma. O incentivo à emigração é uma ação de lideranças religiosas preocupadas com a perda dos tradicionais benefícios e com as mudanças que ameaçavam desestruturar o controle social e político das paróquias. Acrescentamos também outros motivos, como o temor da miséria, a redução cada vez maior dos espaços de atuação e a crescente indignação com a imposição de taxas e proibições do Estado, uma vez que muitos sacerdotes passaram a cair nas malhas da justiça por desrespeito às novas leis.

Portanto, tanto os padres quanto suas famílias se deparavam com mudanças e dificuldades relacionais, consequência das transformações políticas e administrativas nas comunas

${ }^{48}$ ADTV. Carta enviada ao bispo pelo pároco da paróquia de Santo Stefano de Treviso, 12 maio 1877, pasta sacerdote Giobatta Frizzo. 
italianas. As características específicas do grupo ao qual pertenciam, bem como os temores em relação à sobrevivência, eram preocupações que atingiam todos os membros da família, independentemente da profissão que exerciam. O medo da não manutenção de práticas de assistência coletivas, da miséria, da impossibilidade de garantir a união entre os membros, das responsabilidades com o grupo parental próximo e da falta de perspectiva quanto à possibilidade de mobilidade social foi outro fator que incentivou a imigração para a América. Nos locais de partida, os sacerdotes e as famílias não estavam isentos dos problemas e temores vividos pelo restante da população camponesa.

O nascimento do novo Estado italiano, a presença significativa de ideias anticlericais e a destruição do poder temporal da Igreja católica desencadearam reações por parte do papado. Nas últimas décadas do século XIX, crescia, nas dioceses do Vêneto, a difusão de ideias reformistas que procuraram promover virtudes entre os paroquianos. Uma das metas era o controle do clero que não tinha um comportamento adequado, uma vez que devia conduzir seu rebanho no caminho da santidade, garantindo, com isso, o cumprimento dos sacramentos católicos. Na catequese e nas prédicas no púlpito, eram condenados os adversários liberais, considerados os usurpadores dos direitos do papa. Assim, seguindo as orientações proferidas pelas encíclicas papais que condenavam as mudanças da sociedade moderna, muitos padres "intransigentes" buscaram reforçar a influência sobre a população do campo (Gansabin, 1973).

Na década de 1870, quando teve início a emigração para o Brasil meridional, não existia por parte da Igreja uma orientação clara em relação à "fuga" das famílias camponesas da região norte da Itália. A primeira reação foi condenar as transferências. Se, por um lado, alguns padres desestimulavam a emigração, outros buscavam incentivar e organizar a partida de grandes grupos para a América. Não poucos seguiram o caminho percorrido pelos paroquianos, procurando garantir a manutenção e o reforço dos vínculos de solidariedade corporativa com as famílias, ampliar os espaços de atuação, abrir novas oportunidades e reforçar os valores morais e religiosos, agora, porém, nas novas comunidades fundadas pelos imigrantes no território brasileiro.

Geralmente, os sacerdotes que atuavam nas comunas rurais preocupavam-se com os problemas econômicos e sociais vividos pelas famílias da paróquia. Desse modo, em vez de defenderem sua permanência na Itália, passaram a apoiar a emigração para a América como saída para a preservação da estrutura social e religiosa das sociedades camponesas. Para os mais "fanáticos", a exemplo do padre Solerti, as terras do além-mar se apresentavam como o único local possível onde um novo papa poderia ser eleito, e uma "colônia religiosa", fundada.

O contexto de insatisfação e insegurança vivido pela população do campo gerava protestos de todo tipo, incluso emigrar definitivamente, que passou a ser entendido como uma forma de manifestação contra a desestruturação das formas tradicionais de viver em família nas paroquias rurais. O caminho da emigração era um recurso para garantir a liberdade, 
a justiça social, a igualdade, a autonomia e o autogoverno dos indivíduos no além-mar. Defendendo fortemente tais ideias, alguns padres foram os principais articuladores das transferências para terras distantes, uma vez que tal escolha era vista como a melhor saída e abria um leque de possibilidades variadas para os emigrantes, não significando a destruição dos valores, vínculos sociais e estruturas familiares e comunitárias.

Os sacerdotes apresentados neste artigo foram perseguidos pela justiça do Estado italiano por contravenções, desrespeito às leis e à ordem pública. Porém, para além dos laços de confiança existentes entre os camponeses e os padres, aspecto esse fundamental para que os primeiros acreditassem nas orientações dos últimos, teve grande credibilidade a ideia de que na América os italianos poderiam fundar uma "República de Deus". Com esse discurso, o clero giustizialista e milenarista, ${ }^{49}$ que anunciava como castigo divino as epidemias e as crises agrárias, pregava a necessidade de instauração de uma realidade na qual existiria justiça social, liberdade e equidade entre os indivíduos.

As falas dos padres analisados neste trabalho incentivaram grupos de camponeses a abandonar as terras de origem para sair em busca da "República de Deus". Os discursos milenaristas $^{50}$ e giustizialistas foram usados para incentivar os deslocamentos. Porém, para entender a repercussão entre as populações rurais, é necessário analisar o cotidiano das famílias, as características internas, as expectativas, as dificuldades e os temores sentidos pelos camponeses. As motivações das partidas, nas décadas de 1870 e 1880, não devem ser buscadas somente nos problemas econômicos e nos aspectos que indicavam a pobreza das famílias. Antes mesmo da carência de recursos financeiros, foi mais o medo da miséria e da destruição das estruturas tradicionais agregativas que levou à emigração. Somado a isso, um ideal de justiça e liberdade que somente seria conseguido nas terras brasileiras.

Tidos pelas autoridades locais como "fanáticos, ambiciosos e ignorantes", 51 alguns pequenos proprietários também lideraram o deslocamento de conterrâneos para a América. Esse foi o caso do camponês Paulo Bortoluzzi, que, em 1877, partiu com um amplo agregado de parentes e conhecidos da província de Treviso para se estabelecer em uma região colonial no Sul do Brasil. Procuravam se estabelecer em um espaço onde pudessem reviver suas crenças e práticas sociorreligiosas, bem como usufruir de outras vantagens ligadas à sobrevivência e à constituição de comunidades autônomas. O sonho de Bortoluzzi, compartilhado

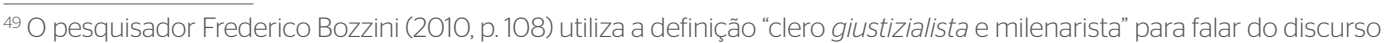
dos padres na região do Vêneto do Ressurgimento diante do avanço das ideias laicas e progressistas. Algumas crenças da cultura religiosa camponesa, como a visão de um Deus vingativo, eram reforçadas pelos padres naquele momento de mudanças sociais e políticas.

50 O termo "milenarista" foi utilizado por Eric Hobsbawm (1970) para entender os movimentos de revolta camponesa no século XIX. O autor destaca que os protestos sociais não podem ser entendidos sem considerar as ideias religiosas e políticas da população, bem como as mudanças econômicas e a modernização capitalista. Os camponeses reagiam contra a introdução de relações jurídicas e sociais, bem como recusavam a nova ordem por meio de um discurso "milenarista, utópico e apocalítico". Os movimentos milenaristas anunciavam a rejeição total de um "mundo perverso e opressivo", impulsionando a busca de um "mundo de justiça e liberdade" (Hobsbawm apud Löwr, 2010, p. 111).

${ }^{51}$ Relação final do Ateneo de Treviso (ACTV. Luiz Bailo, 1878, pasta 13, fascículo 2).
} 
por outros emigrantes que o acompanharam, era o de criar, na província do Rio Grande do Sul, a tal "República de Deus", abandonando, assim, um país anticlerical, dominado pelos intentos antirreligiosos das autoridades liberais italianas e vulnerável aos castigos divinos. ${ }^{52}$ Para além das motivações econômicas e familiares, devemos analisar os aspectos relacionados com os conflitos religiosos e sociais que marcaram o território da península no período pós-unificação como uma perspectiva para entender as escolhas dos camponeses pelo caminho da transferência para o Brasil nas últimas décadas do século XIX.

Considerado "fanático e intransigente", o pároco de Piavon, João Solerti, foi acusado de incentivar a emigração em massa das famílias camponesas do lugar. As autoridades tinham razão, pois o sacerdote vinha afirmando estar a religião católica em decadência na península itálica e, desse modo, orientou o grupo liderado por Paulo Bortoluzzi a "fundar uma colônia religiosa na América". ${ }^{33}$ Como "terra da promissão", o Brasil era descrito como o lugar onde seria possível preservar a cultura religiosa dos camponeses vênetos, além de garantir a sobrevivência, tendo em vista a intensa propaganda que se fazia das riquezas naturais, como terra fértil e abundante. A fome, as pestes e as guerras, diferentemente do que era vivenciado na península, não faria parte das preocupações daqueles que se estabelecessem em território brasileiro. Nesse local, os camponeses encontrariam uma vegetação exuberante e fartura de alimentos, sem dispor de tanto trabalho, sendo, portanto, o Brasil comparado a uma "segunda Canaã", segundo discursos do sacerdote Cavalli.

O caminho da emigração surgia como uma rota de fuga para as mais variadas dificuldades cotidianas, como problemas de ordem econômica, religiosa e política, apresentando-se, também, como uma forma de resistência à desestruturação das dinâmicas tradicionais de assistência social vividas nas comunas rurais. Isso tudo se ligava aos temores alimentados pelos padres de que na pátria a religião católica não teria mais espaço. Sob a acusação de "fanáticos" e "reacionários", os que tradicionalmente se encontravam como guias da população do campo impunham resistências ao avanço das ideias progressistas e patrióticas, motivando, com isso, revoltas contra as autoridades públicas e desejo de conquistar a liberdade na América. Assim, os discursos sobre a terra prometida alimentavam os sonhos de inversão social e justiça, reforçando o imaginário popular camponês da esperança de constituição de um "mundo às avessas". ${ }^{54}$

\footnotetext{
${ }^{52}$ A trajetória do imigrante Paulo Bortoluzzi e a fundação da comunidade do Vale Vêneto foram já abordadas. Sobre esse assunto, ver Vendrame (2016).

${ }^{53}$ ACTV. Brunetti, Antônio. A emigração no distrito de Oderzo. Gazzetta di Treviso, 11, 12, 13 e 17 jan. 1888.

${ }^{54}$ Expressão utilizada por Umberto Ecco (2013) ao falar do imaginário que existia entre os camponeses europeus sobre o tipo de comunidade e vida que levariam nas terras distantes, onde encontrariam fartura de alimentos e terras férteis.
} 


\section{Referências bibliográficas}

ALLEGRA, Luciano. Il parroco: un mediatore fra alta e bassa cultura. In: Storia d'Italia. Annali 4. Turim: Einaudi, 1981. p. 897-947.

BADUZZI, Ernesto. Ernesto Balduzzi parla di Lazzaretti. Intervista estate 1978. Rivista Quadrimestrale di Studi e Ricerche sul Território Amiatino, ano XXVI, n. 72, p. 3-5, 2013.

BIASOLI, Vitor. O catolicismo ultramontano e a conquista de Santa Maria (1870/1920). Santa Maria: UFSM, 2010.

BOZZINI, Federico. L'arciprete e il cavaliere: il Veneto nel risorgimento. Treviso: Santi Quaranta, 2010.

BORZOMATI, Pietro. La parocchia. In: ISNENGHI, Mario. I luoghi della memoria: struture ede eventi dell'Italia unita. Roma: Laterza, 1997. p. 67-91.

BRUNELLO, Piero. Agenti di emigrazione, contandini e immagini dell'America nella provincia de Venezia. In: FRANZINA, Emilio (Org.). Un altro Veneto: saggi e studi di stroria dell'emigrazione nei secoli XIX e XX. Abano Terme: Francisci, 1983. p. 138-174.

CASELLATO, Alessandro. I moti del macinato in Veneto: prima analisi di un caso regionale e spunti per una comparazione. In: VANZETTO, Livio (Org.). Soggettività popolare e Unità d'Italia. Il caso veneto. Venetica. Rivista di Storia Contemporanea, ano XXVI, n. 25, p. 47-78, 2012

ECCO, Umberto. Histórias das terras e lugares lendários. Rio de Janeiro: Record, 2013.

FRANZINA, Emílio. Gli italiani al nuovo mondo: l'emigrazione italiana in America 1492-1942. Milão: Arnoldo Mondadori, 1995.

A grande emigração: o êxodo dos italianos do Vêneto para o Brasil. Campinas: Unicamp, 2006.

GANSABIN, Angelo. Parrocie contadini nel veneto alla fine dell'ottocento. Roma: Edizioni di Storia e Letteratura, 1973.
HOBSBAWM, Eric. Primitivos rebeldes: estudos sobre formas arcaicas de movimentos sociais nos séculos XIX e XX. Rio de Janeiro: Zahar, 1970.

LANARO, Silvio. Società e ideologie nel veneto rurale (18661898). Roma: Edizioni di Storia e Letteratura, 1976.

LEVI, Giovanni. Prefácio. In: OLIVEIRA, Mônica Riberiro de; ALMEIDA, Carla Maria Carvalho (Org.). Exercícios de micro-história. Rio de Janeiro: FGV, 2009. p. 11-16.

Micro-história e história da imigração. In: VENDRAME, Maíra Ines; KARSBURG, Alexandre et. al. Micro-história, trajetórias e imigração. São Leopoldo: Oikos, 2015. p. 246-261. (E-book).

LORENZONI, Júlio. Memórias de um imigrante italiano. Porto Alegre: Sulina, 1975.

LORENZONI, Giulio. Memorie di un emigrante italiano. In: FRANZINA, Emilio (Org.). Vicenza: Istituto per le Ricerche di Storia Sociale e Religiosa; Roma: Viella, 2008.

LÖWR, Michael. Eric Hobsbawm, sociólogo do milenarismo campesino. Revista de Estudos Avançados, n. 24 (68), p. 105-118, 2010.

RIGHI, José V.; BISOGNIN, Edir L.; TORRI, Valmor. Povoadores da quarta colônia. Porto Alegre: EST, 2001.

SCROCCARO, Luigino. Preti, rettori e parroci della chiesa di San Giorgio in Marcon (secoli XII-XX). Venezia: Comunità Parrocchiale di Marcon, set. 2010.

VENDRAME, Maíra Ines. O poder na aldeia: redes sociais, honra familiar e práticas de justiça entre os camponeses italianos (Brasil-Itália). São Leopoldo: Oikos, 2016.

ZANNINI, Andrea; GAZZI, Daniele. Contadini, emigranti, "colonos". Tra le Prealpi venete e il Brasile meridionale: storia e demografia, 178-1910. Treviso: Edizioni Fondazione Benetton Studi Ricerche/Canova, 2003. t. II. 